\title{
Study of bacteria isolated from the foot pad of Spheniscus magellanicus with and without bumblefoot
}

\author{
[Estudo de bactérias isoladas de coxins plantares de Spheniscus magellanicus \\ com e sem bumblefoot] \\ L.G. Osório ${ }^{1}$, M.O. Xavier ${ }^{2}$, S.R.L. Ladeira ${ }^{3}$, R.P. Silva Filho ${ }^{4}$, R.O. Faria ${ }^{3}$, G.D’Á. Vargas ${ }^{3}$, \\ A.L. Cabana ${ }^{4}$, J.R.B. Mello ${ }^{5}$, M.C.A. Meireles ${ }^{3}$ \\ ${ }^{1}$ Aluna de pós-graduação - Universidade Federal do Rio Grande do Sul - Porto Alegre, RS \\ ${ }^{2}$ Faculdade de Medicina - Universidade Federal do Rio Grande - Rio Grande, RS \\ ${ }^{3}$ Universidade Federal de Pelotas - Pelotas, RS \\ ${ }^{4}$ Aluno de pós-graduação - Universidade Federal de Pelotas - Pelotas, RS \\ ${ }^{5}$ Universidade Federal do Rio Grande do Sul - Porto Alegre, RS
}

\begin{abstract}
The bumblefoot or pododermatitis is among the diseases with the highest morbidity in Magellanic penguins, sometimes evolving to septicemia and death. Therefore, this study aimed to relate the main species involved in the disorder, as well as the in vitro susceptibility profile of the microorganisms against routine antimicrobial usage in Veterinary Medicine. During two years in vivo material was harvested from 200 footpads ( $n=100$ animals) for microbiological analysis and in vitro susceptibility tests against the Antibiotic enrofloxacin, streptomycin, penicillin and cephalosporin. Bacteria have been identified both as part of permanent and transient microbiota, also being associated to $100 \%$ of the pododermatitis cases. The most prevalent genus were Staphylococcus and Corynebacterium. The antibiograms of all the isolated bacteria resulted in greater susceptibility of the strains facing cephalosporin, followed by enrofloxacin, streptomycin and penicillin.
\end{abstract}

Keywords: Pododermatitis, Magellanic penguins, Bacterial susceptibility

\section{RESUMO}

O bumblefoot ou pododermatite está entre as afecções de maior morbidade em pinguins-de-magalhães, podendo evoluir para septicemia e óbito. Portanto, o presente estudo objetivou relacionar as principais espécies bacterianas envolvidas na afecção, bem como o perfil de susceptibilidade in vitro destes microrganismos frente a antimicrobianos de uso rotineiro em medicina veterinária. Durante o período de dois anos, foi realizada colheita de material in vivo de 200 coxins plantares ( $\mathrm{n}=100$ animais) para análise microbiológica e testes de susceptibilidade in vitro frente aos antibióticos enrofloxacina, estreptomicina, penicilina e cefalosporina. Bactérias foram identificadas tanto como parte da microbiota permanente quanto da transitória, bem como estiveram associadas a $100 \%$ dos casos de pododermatite. Os gêneros mais prevalentes foram Staphylococcus e Corynebacterium. Os antibiogramas de todas as bactérias isoladas resultaram em maior sensibilidade das cepas frente à cefalosporina, seguida de enrofloxacina, estreptomicina e penicilina.

Palavras-chave: pododermatite, pinguim-de-magalhães, sensibilidade bacteriana

\section{INTRODUCTION}

The Magellanic penguin (Spheniscus magellanicus) population is in clear decline, with growing number of specimens arriving at recovery centers (Garcia-Borboroglu et al., 2006). The bumblefoot or pododermatitis is one of the limiting factors for the rehabilitation of these birds. The syndrome, which can evolve to septicemia and death, is characterized by foot affections, being closely related to captivity

Recebido em 28 de setembro de 2011

Aceito em 1 de outubro de 2012

E-mail: luizaosorio@yahoo.com 
situations (Clarke and Kerry, 1993; Cooper, 2002). There are several species of bacteria related to post-trauma infection of the bumblefoot (Marques et al., 2009), who's progressive characteristic makes the treatment difficult and dependent on the stage of evolution (Cooper, 2002; Cubas and Godoy, 2004).

For the treatment of any infectious disease it is of extreme importance to know the etiological agent and to base the choice of drug on the in vitro sensibility test (Soriano, 2002; López and Oliveira, 2010), as well as knowing the local pathogens and their susceptibility profile (Bail et al., 2006; Lara et al., 2008).

The antibiogram is an in vitro test with the purpose of determining the sensibility of microorganisms facing the antibacterial available in the therapeutic complex. However, the in vitro results obtained can't always be extrapolated to the treatment of the infectious focus. For this is also necessary to know the pharmacokinetics and pharmacodynamics of the tested drugs (Soriano, 2002).

Because of the importance of knowing the main bacteria involved in the local infectious processes and their susceptibility profiles facing different antibiotics, this study aimed to isolate and identify the bacteria in the foot pad of Magellanic penguins with and without pododermatitis kept for rehabilitation, and carry out in vitro susceptibility tests of these bacteria facing four routine usage antimicrobial in veterinary medicine.

\section{MATERIAL AND METHOD}

During the two years all the penguins admitted for rehabilitation at the Marine Animal Recovery Center (CRAM) of the Oceanographic Museum Prof. Eliezer de Carvalho Rios of the Federal University of Rio Grande (FURG) were evaluated for the presence or absence of bumblefoot at the time of entry into the CRAM. Among them, 100 Magellanic penguins which were received without foot injuries were randomly selected and included in the study, being evaluated regarding the development and evolution of pododermatitis during their entire rehabilitation period.

The clinical evaluation occurred through general condition of the penguins and foot analysis. The study sample was comprised of 200 foot pads $(\mathrm{n}=100$ penguins) divided in those without and with pododermatitis in degrees I, II and III. The degree classification was adapted from the classification proposed by Cooper (2002).

Grade I included pads that had a light plantar injury, intact skin and temperature increase in the clinical examination without signs of infection (Fig. 1). Penguins with foot pads classified as grade II had injuries with signs of microorganism contamination no signs of joint injuries, associated with increased foot volume, pain, local temperature increase and lameness, yet the member remained functional (Fig. 2).

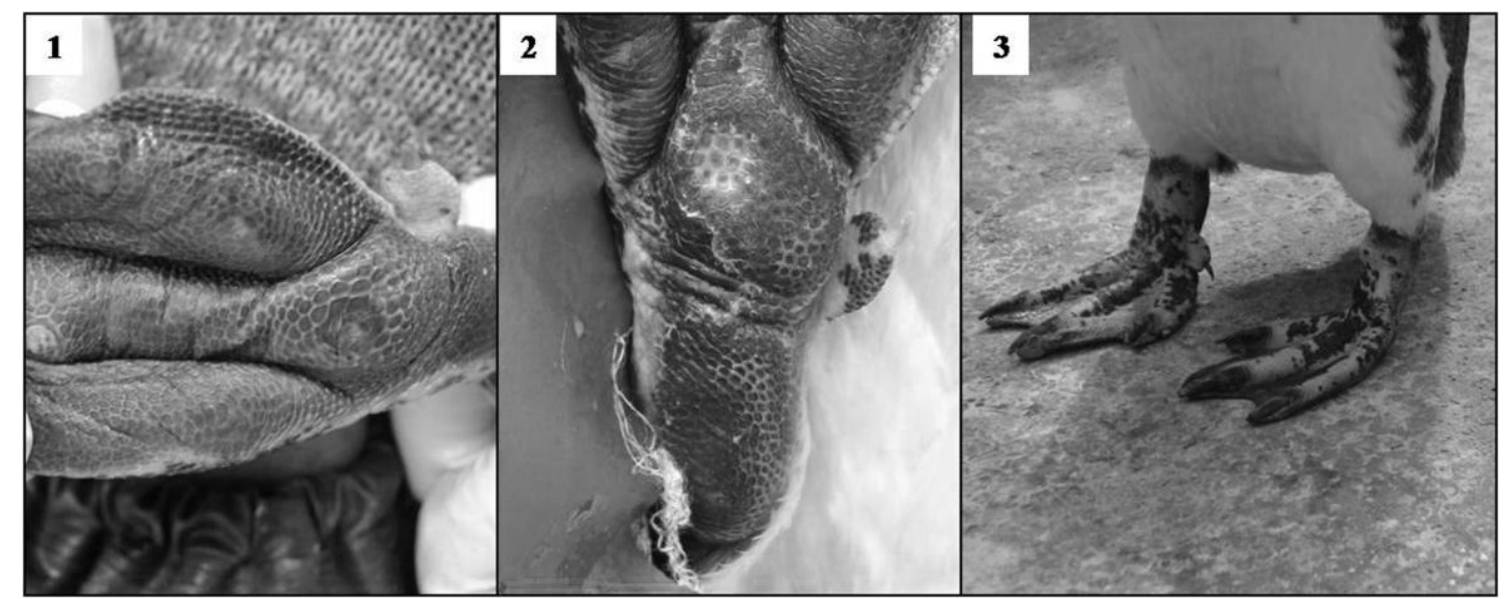

Figure 1. Magellanic penguins with injuries classified as grade I. In 1 and 2 injuries with foot pad discoloration without signs of infection. In 3, normal foot support for the species. 


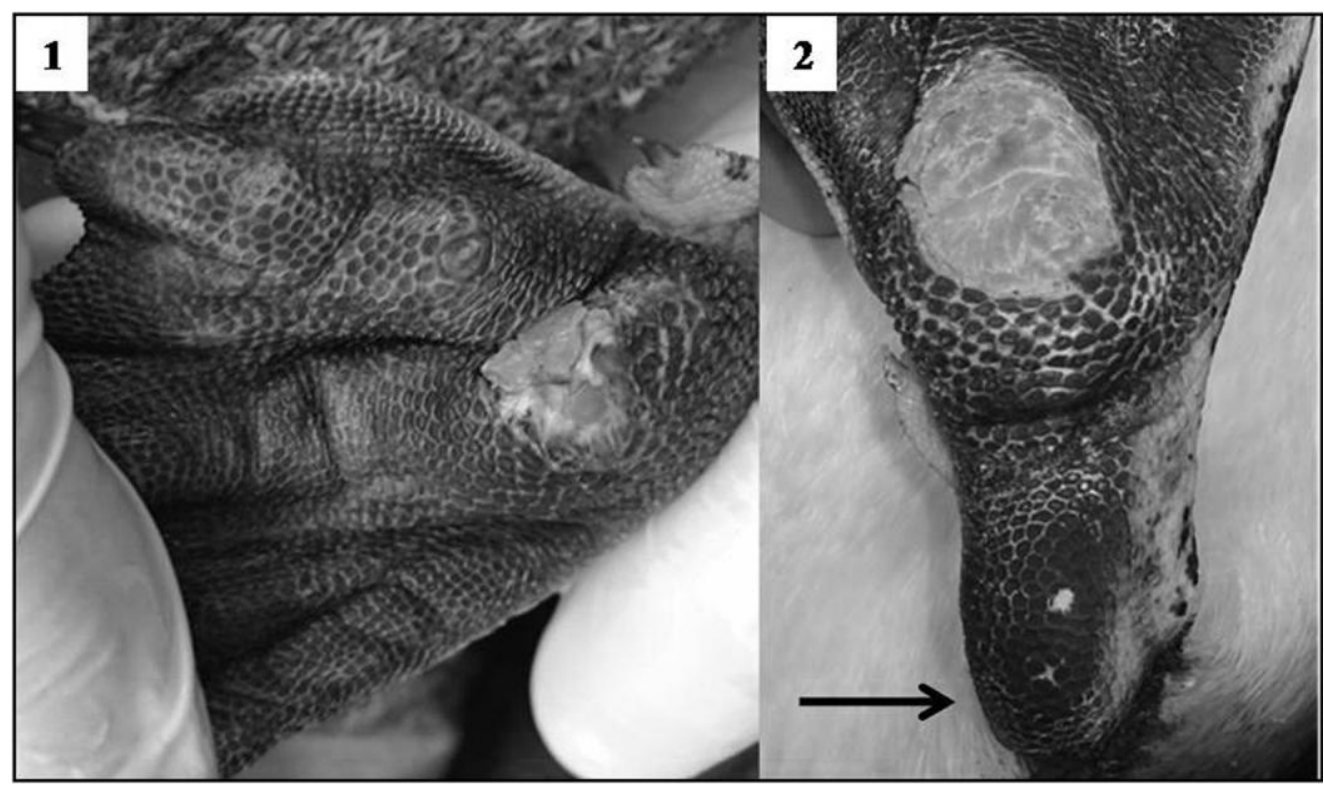

Figure 2. Magellanic penguins classified with grade II bumblefoot. Injuries with signs of infection and the presence of caseous in the foot pad. In 2, detail ofthe absence of injury in the ankle joint.

Penguins with at least one of the pads with grade III had infected injuries, exacerbated increase of volume and external or internal joint injuries, which resulted in partial loss of member function, and abnormal support on the ankle joint. When standing they often leaned and were supported by the caudal vertebrae or were lying down, avoiding putting weight on the injured limb (Fig. 3).

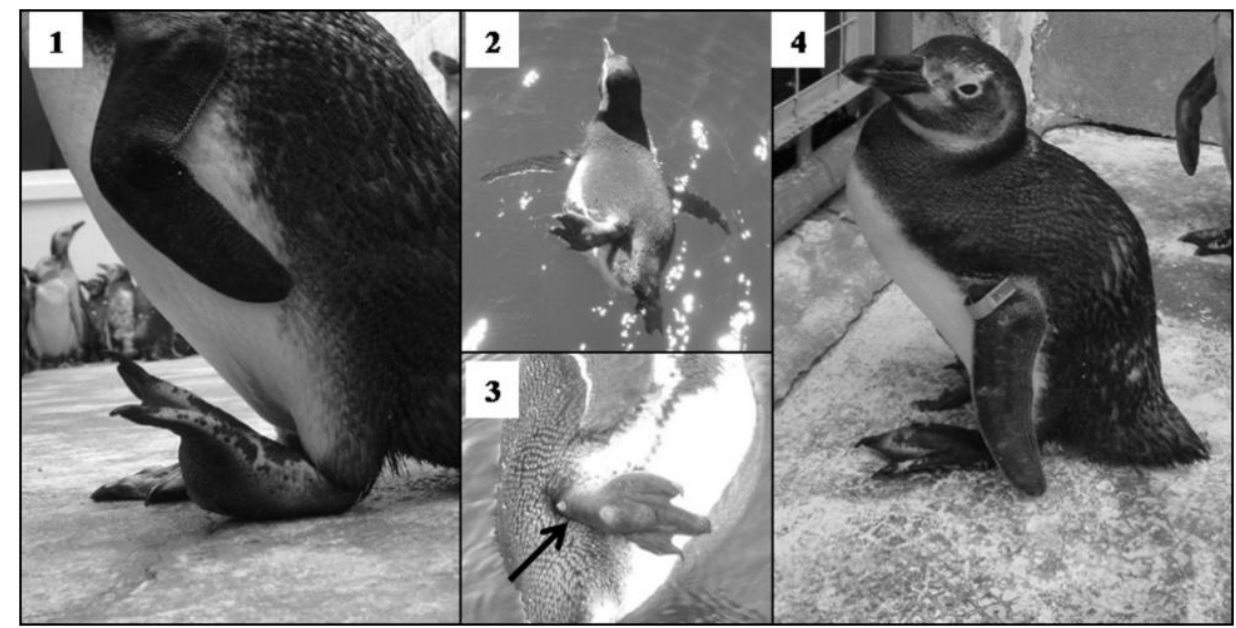

Figure 3. Magellanic penguins sorted with grade III bumblefoot injury. In 1, unusual support on the ankle joint. In 2, change of posture while swimming, with a member down. In 3 , detail of the joint damage. In 4 , postural change.

The in vivo sampling for the penguin foot microbiological evaluation was held during the contention for the clinical assessment of the animal. Contention was performed using the method described by Cubas et al. (2006). Material harvesting from the right or left pads was done, with or without pododermatitis, by rubbing a sterile swab on the foot pad after local cleaning with sterile gauze. In case of lesions located only in the digits, the harvest was done at the injury site. 
The swabs were stored in test tubes with sterile saline in order to prevent sample drying. They were sent to the Department of Bacteriology of the Laboratory of Infectious Diseases, Faculty of Veterinary, Federal University of Pelotas (FaVet - UFPel) in a 24 hour maximum period. The material was processed aseptically in a laminar flow cabinet.

All samples were sown in duplicate by the depletion technique into petri dishes containing blood agar at $5 \%$ of ovine blood and MacConkey agar, incubated at $37^{\circ} \mathrm{C}$ for $24-48$ hours. After this period streaking was done in order to obtain pure cultures when needed. From the necropsy material, foot pad and organs were sown with the untainted side, after splitting with sterile scalpel blade, exposing the injury or inner portion of the organ.

Direct examination of all colonies by Gram stain was conducted, whereupon microorganisms were sorted as cocci, bacilli and coccobacilli and as Gram positive or Gram negative, regarding its micromorphological characteristics. For the species classification, colonies were subjected to various biochemical tests, such as the CAMP test, carbohydrate oxidation test, esculin, gelatin, urea, nitrate and SIM trials. Besides the biochemistry, other characteristics such as hemolysis capacity, catalase and coagulase production were evaluated.

Isolated bacteria were subjected to in vitro susceptibility test facing antimicrobial enrofloxacin, cephalosporin, penicillin and streptomycin with the agar diffusion technique. For the realization of the tests, bacterial inocula were prepared in sterile saline from a scraped off colony, adjusted for 1 in MacFarland scale. The inocula was sown with the aid of a sterile swab in the whole surface of a petri dish containing Muller Hinton culture medium. After the necessary agar absorption time (5 minutes) elapsed, paper discs saturated with high antibiotic concentration were distributed corresponding to $10 \mathrm{UI}$ of penicillin, $30 \mu \mathrm{g}$ of cephalothin, $5 \mu \mathrm{g}$ of enrofloxacin and $10 \mu \mathrm{g}$ of streptomycin. The plates were incubated at $37^{\circ} \mathrm{C}$ for 24 to 48 hours.

The result reading was performed by measuring the diameter of the bacterial growth inhibition halo, according to NCCLS M2-A8 (2003), determining resistance, intermediate resistance or sensitivity.

\section{RESULTS}

From the 200 in vivo foot pads evaluated, $85 \%$ (170/200) showed bacterial growth, regardless of the presence or absence of injuries and their degrees. The 200 samples were divided into two groups, being the first group (Group 1) composed by the 101 members without infection (grades zero and I), and the second (group 2) by the 99 members with infection (grades II and III).

In the first group (without infection), there was bacterial growth in 84 samples $(83.17 \%)$. In 31 $(36.9 \%)$ of these, bacterial associations were found, with eight different patterns. In Group 2 (with infection), bacteria were isolated in 86 samples (88.89\%). Among them, 26 (30.26\%) presented growth of more than one species, with three different types of interaction.

The antibiograms from all isolated bacteria resulted in greater sensitivity of the strains facing the cephalosporin, followed by enrofloxacin, streptomycin and penicillin. These values are described in Table 1.

Concerning the results of the in vitro susceptibility test of the bacterial colonies from pads with infection (grades II and III) and without infection (grades zero and I), greater sensitivity in the strains from non infected members for all the tested antibiotics were obtained, as shown in Table 2.

\section{DISCUSSION}

We found more bacterial interactions, without the predominance of a single species in the animals without infected injury. Such fact is explained considering that in birds with no infection all the isolated microorganisms are balanced, as components of the permanent or transient microbiota. In the infections there is the unbalance between these bacteria, with the predominance of the infection causative agent (Souza and Scarcelli, 2000). 
Study of bacteria isolated...

Table 1. Susceptibility of the microorganisms isolated from foot pads of Magellanic penguins facing cephalosporin, enrofloxacin, streptomycin and penicillin

\begin{tabular}{|c|c|c|c|c|c|c|c|c|c|c|c|c|}
\hline \multirow[t]{2}{*}{ Microorganism } & \multicolumn{3}{|c|}{ Cephalosporin (\%) } & \multicolumn{3}{|c|}{$\begin{array}{l}\text { Enrofloxacin } \\
(\%)\end{array}$} & \multicolumn{3}{|c|}{$\begin{array}{l}\text { Streptomicin } \\
(\%)\end{array}$} & \multicolumn{3}{|c|}{ Penicillin (\%) } \\
\hline & $\mathrm{S}$ & $\mathrm{I}$ & $\mathrm{R}$ & $S$ & $\mathrm{I}$ & $\mathrm{R}$ & $\mathrm{S}$ & $\mathrm{I}$ & $\mathrm{R}$ & $S$ & $\mathrm{I}$ & $\mathrm{R}$ \\
\hline Genus Staph & 100 & 0 & 0 & 93.2 & 0 & 6.8 & 54.1 & 6.6 & 39.3 & 34.7 & 0 & 65.3 \\
\hline - Staphylococcus hemolytic & 100 & 0 & 0 & 33 & 0 & 67 & 0 & 100 & 0 & 0 & 0 & 100 \\
\hline $\begin{array}{l}\text { - Staphylococcus } \\
\text { nonhemolytic }\end{array}$ & 100 & 0 & 0 & 100 & 0 & 0 & 50 & 0 & 50 & 50 & 0 & 50 \\
\hline $\begin{array}{l}\text { - Staphylococcus coagulase } \\
\text { positive }\end{array}$ & 100 & 0 & 0 & 100 & 0 & 0 & 50 & 0 & 50 & 50 & 0 & 50 \\
\hline $\begin{array}{l}\text { - Staphylococcus coagulase } \\
\text { negative }\end{array}$ & 100 & 0 & 0 & 100 & 0 & 0 & 88.9 & 0 & 11.1 & 30.8 & 0 & 69.2 \\
\hline - S. intermedius & 100 & 0 & 0 & 100 & 0 & 0 & 0 & 100 & 0 & 0 & 0 & 100 \\
\hline - S. aureus & 100 & 0 & 0 & 50 & 0 & 50 & 0 & 50 & 50 & 0 & 0 & 100 \\
\hline - Staphylococcus sp. & 100 & 0 & 0 & 97.9 & 0 & 2.1 & 43.7 & 0 & 56.3 & 38 & 0 & 62 \\
\hline ium sp. & 92.9 & 0 & 7.1 & 61.5 & 23.1 & 15.4 & 66.7 & 13.3 & 20 & 50 & 0 & 50 \\
\hline Kurthia s & 100 & 0 & 0 & 100 & 0 & 0 & 0 & 0 & 100 & 0 & 0 & 100 \\
\hline Alcaligenes sp. & 100 & 0 & 0 & 0 & 100 & 0 & 0 & 0 & 100 & 100 & 0 & 0 \\
\hline E. coli & 0 & 33.3 & 66.7 & 100 & 0 & 0 & 33.3 & 0 & 66.7 & 0 & 0 & 100 \\
\hline Total & 95.3 & 3.5 & 1.2 & 88.2 & 4.3 & 7.5 & 55.5 & 6.2 & 38.3 & 36.7 & 0 & 63.3 \\
\hline
\end{tabular}

$\mathrm{S}=$ susceptibility, $\mathrm{I}=$ intermediate susceptibility, $\mathrm{R}=$ resistant

Table 2. Susceptibility relation of the microorganisms isolated from foot pads of Magellanic penguins with and without infection, against antibiotics of routine usage in veterinary medicine

\begin{tabular}{l|c|c}
\hline \multirow{2}{*}{ Antimicrobial } & Origin & Microorganism \\
\cline { 2 - 3 } & With infection & Without infection \\
\hline Cephalosporin & $94.12 \%$ & $95.45 \%$ \\
Enrofloxacin & $82.76 \%$ & $91.89 \%$ \\
Streptomycin & $34.1 \%$ & $65 \%$ \\
Penicillin & $32.76 \%$ & $45.1 \%$ \\
\hline
\end{tabular}

In all evaluated cushions, the bacteria with the higher isolation ratio were from the Staphylococcus genus, followed by Corynebacterium. The likely cause of the high number of isolates from penguins' plantar cushion without installed infection indicates that both are inhabitants of the normal flora of the skin or other systems in these birds. This is mainly regarding Corynebacterium spp., since there are no studies in literature that refer to this genus as part of the environmental biota, unlike what happens with Staphylococcus spp. (Cubas and Godoy, 2004). Goyache et al. (2003) demonstrated $C$. spheniscorum isolated together with Staphylococcus sciuri as an inhabitant of the natural microflora of the cloaca in the Spheniscus magellanicus. The high number of isolates from infected injuries is due to the opportunistic action of the agents, causing infection when there is a breach of balance of the body's natural defenses (Souza and Scarcelli, 2000). This is as expected regarding the Staphylococcus genus, which has already been related to other pododermatitis cases and is considered the most common etiological agent in skin infections (Cubas and Godoy, 2004).

Previous researches showed that in $95 \%$ of the infection cases by the classical species in the Enterobacteriaceae microorganism group are found, among which include E. coli and Proteus (Brasil, 2004), as occurred in this study. The Proteus spp. has been isolated only from animals with infected plantar lesions, not being identified in any animal with degree zero or I of bumblefoot. This data is in accordance with the described by Cantón and Moreno (2006) who related the bacteria as uncommon in healthy individuals. The $E$. coli was isolated in different types of injuries, but in greater numbers in animals with infection, confirming the opportunistic pathogenic potential of strains of this species, which in association with other genus is responsible for most cases of enteritis in captive penguins (Clarke and Kerry, 1993). In has also been isolated in several cases of 
suppurative arthritis in chickens, causing concern in poultry production (Fallavena et al., 1991).

The study showed high number of bacterial isolates belonging to the transient or permanent microbiota of gastrointestinal tract, such as Staphylococcus spp., Corynebacterium spp. E.coli and Proteus spp. Due to remaining on station for long periods in dry areas, weakened penguins end up having contact with their own excreta, thus, gastrointestinal microorganisms can configure important contaminants of plantar wounds.

Bacteria Alcaligenes sp., and Kurthia sp. behaved as part of skin microbiota of the penguins, with probable transitory involvement, due to the low number of isolates, that occurred only in healthy cushions. Both genders have questionable clinical significance (Brasil, 2004), unlike the Streptococcus genus bacteria, reported in this study, in which the genus was only isolated from clinical cases. This genus is considered one of the major infectious agents of poultry (Cubas e Godoy, 2004).

Although the bacterial resistance configures a problem in population often submitted to antibiotic therapy (Baccaro et al., 2002), this reality has also been related in wild birds (Santos et al., 2010), corroborating this study, in which the strains isolated from Magellanic penguins without previous antibiotics treatment presented varied susceptibility facing the tested antimicrobial. Therefore, using the data obtained in this study, enrofloxacin and cephalosporin may be indicated in empiric bumblefoot treatment, while the use of penicillin and streptomycin is not indicated, since drugs with more than $20 \%$ of local resistance are not recommended for empirical treatment (Naber, 2000). Such data contributes to the Magellanic penguins' rehabilitation, since the study was carried out in the main penguin rehabilitation center in Brazil.

The cephalosporin was the drug with the greater activity against most strains, with high susceptibility rate against the two most prevalent genus in the study: Staphylococcus spp. (100\%) and Corynebacterium spp. (90\%). This effectiveness corroborates with in vitro experiment using Staphylococcus spp. isolated cracid (Santos et al., 2010), and in vivo studies in cattle, which showed a cure rate above $80 \%$ in infections involving these agents (Moreira et al., 2010). This antibiotic is also indicated in the treatment of colibacilosis (Climeni et al., 2009). However, in the present study, the E. coli strains susceptibility rate were null, as already demonstrated by Lara (2008). Baccaro et al. (2002) attributes this resistance to the indiscriminate use of antibiotics in veterinary medicine. However, there are studies that show susceptibility rates of $60 \%$ to $80 \%$ (Vieira et al., 2007; Moreira, 2010)

Enrofloxacin was the second antibiotic with the best in vitro response, with a higher $E$. coli susceptibility rate than expected, according to the literature (Baccaro, 2002), and lower Staphylococcus spp. and Corynebacterium spp. strain resistance (Fabiano et al., 2008).

Streptomycin does not have good activity in conditions with the involvement of $E$. coli, being indicated in the treatment of pododermatitis caused by Staphylococcus spp. and Corynebacterium spp. (Baccaro, 2002). But in this study, the resistance rates against the three genus demonstrated that the antimicrobial should not be indicated in the treatment of bumblefoot involving these agents. The same repeats with penicillin, drug with higher percentage of resistance of the tested strains. Corroborating with previous studies with bacteria of the genus Corynebacterium (Abreu et al., 2008), Staphylococcus (Moreira et al., 2010) and E. coli (Baccaro, 2002).

\section{CONCLUSION}

Bacteria were identified either as a permanent or transient part of the microbiota and associated with $100 \%$ of pododermatitis cases. The most prevalent bacterial genera were Staphylococcus e Corynebacterium. Cefalosporin was the antibiotic with the best activity on evaluated strains, followed by enrofloxaxin and streptomycin. On the other hand, penicillin was the less effective antibiotic, with isolates resistance of more than $60 \%$. 


\section{ACKNOWLEDGMENTS}

CRAM, CNPq, CAPES - Financial Support sources: $\mathrm{CNPq}$ and CAPES.

\section{REFERENCES}

ABREU, S.R.O.; MOTA, R.A.; PINHEIRO JR, J.W. et al. Perfil de sensibilidade antimicrobiana in vitro de isolados de Corynebacterium pseudotuberculosis de caprinos e ovinos com linfadenite caseosa no sertão de Pernambuco, Brasil. Vet. Zootec., v.15, p.502-509, 2008.

BACCARO, M.R.; MORENO, A.M.; CORRÊA, A. et al. Resistência antimicrobiana de amostras de Escherichia coli isoladas de fezes de leitões com diarreia. Arq. Inst. Biol. São Paulo, v.69, p.15-18, 2002.

BAIL, L.; ITO, C.A.S.; ESMERINO, L.A. Infecção do trato urinário: comparação entre o perfil de susceptibilidade e a terapia empírica com antimicrobianos. RBAC., v.38, p.51-56, 2006.

BRASIL. ANVISA - Agência Nacional de Vigilância Sanitária. Detecção e Identificação de Bactérias de Importância Médica - Módulo V, 2004. Available in: <www.anvisa.gov.br/servicosaude/manuais/micr obiologia.asp>. Accessed in: 24 jan. 2010.

CANTÓN, R.; MORENO, M.P.S. Proteus penneri: Microbiologia clínica. SEIMC, 2006. Available in: <www.seimc.org>. Accessed: 21 jan. 2010.

CLARKE, J.; KERRY, K.R. Diseases and Parasites of penguins. Korean J. Polar Res., v.4, p.79-96, 1993.

CLIMENI, B.S.O.; DELLALIBERA, F.L.; MONTEIRO, M.V. et al. Cefalosporinas: sua origem, uso e função em animais de grande e pequeno porte. Rev. Cient. Elet. Med. Vet., v.12, p.1-8, 2009.

COOPER, J.E. Birds of Prey, Health and disease. 3. ed. USA: Ed. Blackwell, 2002. 345p.

CUBAS, Z.S.; GODOY, S.N. Algumas doenças de aves ornamentais. 2004. Available in: <www.canarilalmada.com/download/download/ Dossierdedoencas.pdf > . Accessed: 3 sept. 2011.
CUBAS, Z.S.; SILVA, J.C.R.; CATÃO-DIAS, J.L. Tratado de animais selvagens, Medicina Veterinária. 1. ed. Ed. Roca, 2006. 1354p.

FABIANO, T.L.T.; ÁVILA, B.H.P.; DIAS, C.C. et al. Genetic similary between Staphylococcus sp. isolated from human and hospital settings, and susceptibility to different antimicrobials. Braz. J. Microbiol., v.38, p.652-657, 2008.

FALLAVENA, L.C.B.; SALLE, C.T.P.; MORAES, H.L.S. et al. Problemas locomotores em frangos de três linhagens do tipo corte: I. Aspectos clínicos, ocorrência de discondroplasia tibial e encurvamento do tibiotarso. Arq. Bras. Med. Vet. Zootec., v.43, p.37-47, 1991.

GARCIA-BORBOROGLU, P.; BOERSMA, P.D.; RUOPPOLO, V. et al. Chronic oil pollution harms Magellanic penguins in the Southwest Atlantic. Marine Pollut. Bulle., v.52, p.193-198, 2006.

GOYACHE, J.; VELA, A.I.; COLLINS, M.D. et al. Corynebacterium spheniscorum sp. nov., isolated from the cloacae of wild penguins. Int. J. Syst. Evol. Microbiol., v.53, p.43-46, 2003.

LARA, V.M.; DONADELI, M.P.; CRUZ, F.S.F.; CARREGARO, A.B. Multirresistência antimicrobiana em cepas de Escherichia coli isoladas de cadelas com piometra. Arq. Bras. Med. Vet. Zootec., v.60, p.1032-1034, 2008.

LÓPEZ, H.S.; OLVERA, L.G. Consideraciones Farmacológicas de la Antibioticoterapia em Aves. Asociación Ecuatoriana de Buiatría, 2005. Available in: <www.buiatriaecuador.org/memorias/farmacolog ia/images/memorias/05_AntibioticoterAnti_aves. pdf>. Accessed: 04 sept. 2011.

MARQUES, M.V.R.; RESENDE, J.S.; DONATTI, R.V. et al. A bumblefoot outbreak and fatal septicemia in captive aquatic birds in Brazil. Cienc. Rural, v.39, p.1905-1907, 2009.

MOREIRA, P.C.; SILVA, L.A.F.; MESQUITA, A.J. Resistência de Staphylococcus coagulase positiva e Streptococcus sp. isolados do leite de vacas com mastite clínica na bacia leiteira de Goiânia. Anais Esc. Agron. Vet., v.27, p.61-68, 1997.

NABER, K.G. Treatment options for acute uncomplicated cystitis in adults. JAC., v.46, p.23-27, 2000. 
NCCLS M2-A8 - National Committee for Clinical Laboratory Standars. Performance Standards for Antimicrobial Disk Susceptibility Tests; Approved Standard - Eighth Edition, 2003.

SANTOS, H.F.; FLÔRES, M.L.; LARA, V.M. et al. Microbiota cloacal aeróbia de cracídeos cativos no Rio Grande do Sul e sua susceptibilidade a antimicrobianos. Pesq. Vet. Bras., v.30, p.1077-1082, 2010.

SORIANO, F. Aspectos farmacocinéticos y farmacodinâmicos para la lectura interpretada del antibiograma. Enferm. Infecc. Microbiol. Clin., v.20, p.407-12, 2002.
SOUZA, C.A.I.; SCARCELLI, E. Agressão por microrganismos da microbiota endógena. Arq. Inst. Biol. São Paulo, v.67, p.275-281, 2000.

VIEIRA, J.M.S.; SARAIVA, R.M.C.; MENDONÇA, L.C.V. et al. Suscetibilidade antimicrobiana de bactérias isoladas de infecções do trato urinário de pacientes atendidos no Hospital Universitário Bettina Ferro de Souza, Belém - PA. RBAC, v.39, p.119-121, 2007. 